\title{
Starting Points for Planning Business Zones in Slovenia in the Post-independence Period
}

\author{
Gregor $\check{C ̆ o k}^{1, *}$ \\ ${ }^{1}$ University of Ljubljana, 1000 Zoisova 12, Ljubljana, Slovenia
}

\begin{abstract}
In Slovenia, during the period of transition practically all mechanisms for steering economic and spatial development changed. The planning of business zones is part of this framework; business zones are competitive business environments for the placement of economic activities in the physical space. Over the past 25 years, their design was influenced by various factors: introduction of free market principles, privatisation of social property, and interests of the young state to establish, using proper strategies and financial initiatives, an efficient network of zones as drivers of economic development. Despite the ambitious plans and adopted strategic spatial planning acts at the national level we nowadays find that the zones, in their current spatial and administrative form, are not an efficient enough development mechanism. The focus of the study was to define the starting points as the basis for planning business zones and shaping policies to improve the existing situation. To improve the business competitiveness of the existing zones and their role in the planning and design system, we will have to set up a more efficient data updating system and form a broader approach to their management, promotion, and marketing.
\end{abstract}

\section{Introduction}

After declaring independence in 1991, Slovenia entered a transitional stage, where its socio-political, economic, and spatial development concept changed completely. By introducing the sustainable development doctrine [1,2], liberal principles of the free market, and the democratically founded local self-governance, the established practice of planning activities in space changed significantly as well.

The former planned socialist (social, economic, and spatial) development, which was in SFRY mostly realised within the constraint of the public finances [3], was replaced by the concept of selective investments following the principle of supply and demand.

Slovenia, as many other Eastern Bloc countries (Hungary, Poland, Czech Republic, Slovakia, etc.), formally opened out to western investments [4, 5], which, through establishment of enterprises under the "new democracies", mostly consumed cheaper labour force, more flexible environmental norms, and the "transitional" tax legislation

In the first years of independence, at the start of privatisation of social property, relatively low productivity, and the loss of established markets of the former SFRY

* Corresponding author: gregor.cok@,fa.uni-lj.si 
(Socialist Federal Republic of Yugoslavia) Slovenia's economy evidently stagnated. After a few years of consolidation, new development perspectives were formed. The state began to implement various measures to improve the business environment and, as a result, strengthen economic growth (tax policy, subsidies, attracting foreign investment, etc.) [6].

This includes the measure of building new and revitalise existing "business zones" to, above all, ease the establishment of new companies and secure their long-term existence in individual locations. Today, 25 years later, the spatial planning and economic professional community is trying to establish whether this measure was, in fact, effective.

The establishment of new zones resulted from various interests and motivations, which indeed followed the objectives of establishing a competitive business environment (strategic locations, cheap land, simple building conditions, etc.).

In the era of transition, the field of planning and design also changed considerably. Furthermore, spatial legislation, the financing method of public transport and municipal infrastructure (public-private partnerships), and the philosophy of real-estate investments itself changed [7]. Spatial capacities for site selection, placement, and organisation of economic activities in the physical space nowadays mostly take place as two spatial forms:

(a) old zones: former industrial, craft, storage, and logistical zones, as a consequence of extensive industrialisation of the territory of RS after WWII,

(b) new zones in new locations: established on the basis of various interests (needs of local entrepreneurship, national development strategies, investment motivations, etc.).

From the spatial planning perspective, the significance of these zones is two-fold. Economically, they are drivers of economic development while, spatially, these are extensive areas of urban fabric with various impacts on the environment. In this sense, "planning regulators" are important; through them we implement the goals set for all regulatory areas (settlement, demography, infrastructure, agriculture, etc.). This perspective is particularly important when preparing spatial development plans, where we have to coordinate various planning starting points and sectoral goals.

\section{The problem and a hypothesis}

In RS, the situation related to the "range of spatial development capacities" is nowadays the consequence of various factors from our recent past.

During the privatisation of former business zones after 1991, their ownership and spatial structure fragmented, which decreased the possibility of an efficient programmatic and structural regulation. A wide range of activities in the domain of small entrepreneurship (mostly trade and business activities) was introduced in these locations, while there was soon a lack of appropriate development areas for new investors, which resulted in the establishment of many new zones throughout Slovenia.

In the national spatial legislation and practice in 1995-2015 there was no efficient methodology to regulate the existing, and plan the new, zones, therefore regions and municipalities addressed this problem differently. Today, the problem is evident in an extensive network of various types of zones (approx. 400 zones); these zones have one thing in common: in the real-estate market and when implementing development programmes they are not recognised as an efficient tool for steering economic and spatial development (there is a lack of a common operator, of a single programmatic typology, of efficient promotion and marketing, of data on available internal areas, building conditions, etc.).

Under such conditions it is not possible to create an attractive business environment as are those in competitive locations in the wider region (Italy, Austria). This situation is confirmed by many expert guidelines and the recently conducted survey among foreign investors, by SPIRIT Slovenia - Public Agency for Entrepreneurship, Internationalization, 
Foreign Investments and Technology. The survey showed that among the key obstacles for foreign investment in Slovenia there are problems related to the spatial perspective (high prices and/or availability of developed land, complex procedures to obtain various permits, lack of support activities, etc.). In this framework, the following research question was put forward:

What programmatic and spatial starting points provided the basis to plan business zones in the era of transition?

\section{Hypothesis}

The changed socio-economic conditions shaped the doctrine of supply and demand also in relation to investing into business zones. In this framework, despite considering, "in principle", strategic development starting points to strengthen national competitiveness, new, market-oriented implementing documents were produced. These mostly satisfied the current demand, following the principle of "anybody, anything, anywhere". The consequences of the non-systematic approach are reflected in the "regulatory inefficiency" of the business zone network as an instrument in the planning and design system.

\section{Methodology}

The focus of the study was to define all planning and design starting points, based on which business zones were planned over the past 25 years. This was done in two stages. In the first stage, a descriptive research method was applied to analyse 15 reference documents:

(1) strategic spatial development documents (3 documents at the national level),

(2) implementing spatial planning documents at the regional level (2 documents),

(3) implementing spatial planning documents at the local level, and an expert study for their preparation $(5+5$ documents).

From each document we took, separately for textual and graphical parts, all the mentioned starting points and justifications underlying the concept of developing the existing and new zones.

In the second stage a comparative research method was used, which was put in place in two steps. In the first step we reviewed the interim results and selected two groups of starting points: (a) global starting points: planning level, arising from the objectives of the Spatial Development Strategy (state, region, municipality) and (b) implementing starting points: project level, determining zone planning (programmatic design, size of zone, site characteristics). Then we categorised the starting points from each group according to their meaning into: (a) economic starting points and (b) spatial starting points. In the second step, conclusions were drawn up and the guidelines to remedy the existing situation were proposed.

\section{Results}

In the study we analysed three documents that in the period after 1991 strategically best defined the basic starting points for planning and designing business zones. They were as follows:

(1) Spatial Development Policy of the Republic of Slovenia (2002) [8] - defines the national vision of spatial development and is the umbrella document for coordination of sectoral policies in implementing sectoral measures and projects.

In this sense it does not provide detailed planning parameters for business zones, but rather it provides guidelines for their spatial integration (e.g. priority macro locations for 
economic development: border areas and regional centres; abandonment of energyconsuming activities; provision of developed land at the local level for development of local economy).

(2) Economic Development Strategy of Slovenia (SGRS) 2001-2006 [9] - its central goal is to achieve "complex competitiveness of the state" leading into shaping an efficient national economy for producing internationally competitive products and services. The spatial perspective of organising economic activities is integrated into various development measures affecting their range and territorial distribution.

This is mostly about revitalisation programmes for local development potentials and cooperation of the state in shaping a supporting environment for functioning of the existing and new companies (Table 1).

Table 1. Development measures and a "summary of starting points" for developing business zones when achieving complex competitiveness of the state.

\begin{tabular}{|c|c|}
\hline $\begin{array}{l}\text { A Regionally and spatially coherent } \\
\text { development } \\
\text { - Placement of new business zones is the } \\
\text { basis to attract new investments and reduce } \\
\text { regional disparities. }\end{array}$ & $\begin{array}{c}\text { F Information and communication } \\
\text { infrastructure } \\
\text { - Its development will bring forward the } \\
\text { surrounding locations, increase the possibility } \\
\text { of home working, and viability of creating } \\
\text { smaller business zones. }\end{array}$ \\
\hline $\begin{array}{c}\text { B Strengthening the role of spatial planning } \\
\text { as a factor of economic development } \\
\text { - In regional and local spatial documents it is } \\
\text { necessary to provide for sufficient and } \\
\text { economically attractive areas and define the } \\
\text { various types of spatial integration of } \\
\text { economic activities (point and continuous } \\
\text { zones). }\end{array}$ & $\begin{array}{l}\text { G Facilitating the development of small and } \\
\text { medium-sized enterprises } \\
\text { - By providing infrastructure, land and other } \\
\text { elements, the state will participate in the } \\
\text { shaping of an attractive support environment } \\
\text { and thus directly impact the establishment and } \\
\text { distribution of business zones. }\end{array}$ \\
\hline $\begin{array}{c}\text { C A supportive environment as a set of } \\
\text { elements to facilitate technological } \\
\text { development } \\
\text { - Material infrastructure is an important part } \\
\text { of the supportive environment. }\end{array}$ & $\begin{array}{c}\text { H Foreign direct investment (FDI) } \\
\text { - With various instruments, measures, and } \\
\text { grants, the state will directly influence the } \\
\text { location of business zones intended to attract } \\
\text { FDI. }\end{array}$ \\
\hline $\begin{array}{l}\text { D Supporting the growth of private sector } \\
\text { competitiveness } \\
\text { - The enterprises whose expansion and } \\
\text { development will grow beyond home } \\
\text { working will move their businesses into the } \\
\text { zone, where, in turn, the demand for new } \\
\text { areas and locations will increase. }\end{array}$ & $\begin{array}{l}\text { I Removal of administrative barriers (red tape } \\
\text { reduction) } \\
\text { - Along with simplification of administrative } \\
\text { procedures we need to produce modern, more } \\
\text { flexible spatial plans. }\end{array}$ \\
\hline $\begin{array}{c}\text { E Allocation of labour force } \\
\text { - Distribution of business zones plays an } \\
\text { important role in relation to labour } \\
\text { commuting; a larger number of zones reduces } \\
\text { the home-work-home flows. }\end{array}$ & $\begin{array}{l}\text { J Economic infrastructure } \\
\text { - Economic infrastructure is the central } \\
\text { locational criterion in introducing new zones, } \\
\text { its development will increase the number of } \\
\text { locations and the quality of their services. }\end{array}$ \\
\hline
\end{tabular}

(3) Spatial Development Strategy of Slovenia (SPRS 2004) [10] - is the next key document that defines the national spatial and development goals and the institutional mechanisms to achieve them. It also defines the development measures with the starting points for developing business zones (Table 2). 
Table 2. Development measures and a "summary of starting points" for developing business zones when achieving coordinated spatial development.

\begin{tabular}{|c|c|}
\hline $\begin{array}{l}\text { A Polycentric structure development } \\
\text { - The concept of priority development will } \\
\text { provide a range of jobs, housing, and public } \\
\text { services in locations of interest. A strategy of } \\
\text { developing new business zones will have an } \\
\text { important role in this. }\end{array}$ & $\begin{array}{c}\text { E Areas of production activities } \\
\text { - Contemporary location criteria for optimum } \\
\text { integration of economic activities in the } \\
\text { physical space need to be defined. } \\
\text { - In siting new zones, the viability of the } \\
\text { development needs to be justified (the } \\
\text { existing capacities checked). }\end{array}$ \\
\hline $\begin{array}{c}\text { B Border and disadvantaged areas } \\
\text { - Establishment of small business zones for } \\
\text { centres with a narrow impact area. } \\
\text { - Zone typology needs to be defined which will } \\
\text { comply with the specific development demands. }\end{array}$ & $\begin{array}{c}\text { F Development of cities, towns, and } \\
\text { settlements } \\
\text { - Each economic activity contributes to } \\
\text { global development. } \\
\text { - Home working is encouraged along with } \\
\text { collective organisation in the framework of } \\
\text { business zones. }\end{array}$ \\
\hline $\begin{array}{l}\text { C Vitality and attractiveness of rural regions } \\
\text { - Encouraging entrepreneurship to form a } \\
\text { dispersed structure of individual economic } \\
\text { structures. This trend is already evident and } \\
\text { highlights the need for a specific spatial } \\
\text { regulation. }\end{array}$ & $\begin{array}{l}\text { G Regional integration } \\
\text { - In spatial planning documents we need to } \\
\text { define the criteria that will provide the basis } \\
\text { for determining local attractiveness in the site } \\
\text { selection of regional business zones. }\end{array}$ \\
\hline $\begin{array}{l}\text { D Development of settlement } \\
\text { - In this context, different zones in relation to the } \\
\text { specific types of urban settlements have to be } \\
\text { designed. } \\
\text { - It is necessary to provide the conditions for } \\
\text { developing business zones with modern } \\
\text { equipment and technology parks, particularly in } \\
\text { Ljubljana, Maribor, and Koper, and in regional } \\
\text { centres with a strong background in capital and } \\
\text { knowledge in the fields of high technology and } \\
\text { labour force. }\end{array}$ & $\begin{array}{c}\text { H Transport terminals } \\
\text { - Development of a transport logistics } \\
\text { terminal will importantly affect the locations } \\
\text { of business zones of regional and national } \\
\text { significance. }\end{array}$ \\
\hline
\end{tabular}

All three documents provide distinctly "strategic starting points", whose implementation in lower-ranking documents and their actual impact is difficult to assess reliably. We found that many of these "starting points" (e.g. polycentric development, development of cities and infrastructure) were (in a somewhat different formulation) included already in the previous generation of the so-called "socialist" development strategies.

\section{Implementing spatial planning documents at the regional level}

In the previous decade, regional spatial documents were produced (the so-called Regional Concept of Spatial Development - RZPR) as partner documents between the state and municipalities.

This is a lower level of strategic and implementing documents that, on the one hand, summarised the starting points of national development strategies and, on the other hand, the municipal needs and development trends significant for both the individual municipalities and the region as a whole.

In the framework of this study we analysed 2 cases of RZPR. We found that there was a blending of "differently detailed" starting points for defining the concept of developing business zones. In one case (RZPR of SE Slovenia, 2006) [11] for the field of business 
zones a special expert study was produced (with detailed definition of location criteria for their placement), while in the second case (RZPR for the South Primorska Region) [12] the starting points were based on the content of the Regional Development Plan (RRP) [13]. In both cases, the spatial planning documents were not produced to the level of detail that would allow for definition of specific locations and the extent of individual zones. We also found that the regional scale was optimal for strategic planning of a zone network of various typologies, as it represents the appropriate framework for coordination of individual spatial interests.

\section{Implementing spatial planning documents at the local level and the expert study for their elaboration}

With the declaration of independence in 1991, all Slovenian municipalities had applicable spatial documents produced mostly in the period of 1980-90. They legitimised zoned land use with relatively large development reserves. All the amendments of these plans, or the production of new plans (the so-called OPNs) are largely based on the previous distribution of activities in space. In this study, we analysed 5 cases of spatial planning documents from various parts of Slovenia (3 OPN drafts: Žalec, Piran, Izola [14, 15, 16] and 2 cases of recently adopted OPNs: Ljubljana and Novo mesto, $[17,18]$ ). To specify the starting points as the basis for the planning of the business zones in these documents we also analysed the relevant expert groundwork, [19, 20-23].

We found that the starting points are mostly covered in the chapter "Analysis of the spatial situation and trends" (AST). These analyses have different levels of detail and quality in terms of: (a) available financial frameworks and timeframes, and human capacity of their producers, (b) client cooperation, and (c) data availability.

By means of reviewing the individual content of spatial documents and their expert groundwork (Table 3) we found that when preparing the document the key problem of defining the planning and project starting points was the lack of reliable data: (a) on development potential of existing locations and (b) on actual (topical and envisaged) needs for establishing new zones.

By analysing the cartographic groundwork determining zoned land use we found that the traditional locations of the sites for industry, craft industry, storage, and logistics in all the cases analysed mostly preserve the existing scope.

The areas that give rise to concern from the environmental perspective, or were simply overgrown by cities/towns during their intensive growth, are cancelled.

These starting points are defined quite in detail in the strategic part of spatial plans, which also define other starting points, resulting from umbrella strategic documents at the state level.

The starting points regarding the data on the actual needs and prognosis of long-term development (quota of necessary and reserve areas, realisation timetable, programmatic design of individual zone types) are far more indeterminate. These starting points were designed with "varying quality" during the production of the expert study. 
Table 3. Expert study for OPNs (a summary of findings): analysis parameters that the producers addressed as the starting points for producing the strategy for developing business zones.

\begin{tabular}{|c|c|c|}
\hline \multicolumn{3}{|c|}{$\begin{array}{l}\text { Expert study for designing the strategy for developing business zones in producing OPNs, } \\
\text { a summary of the } 5 \text { cases of expert studies }\end{array}$} \\
\hline $\begin{array}{c}\text { AST activity } \\
\text { (analysis of the spatial } \\
\text { situation and trends) }\end{array}$ & $\begin{array}{l}\text { Analysis parameters demonstrating } \\
\text { project starting points }\end{array}$ & $\begin{array}{c}\text { Precision rate of } \\
\text { data acquisition and } \\
\text { processing (1 to } 5)\end{array}$ \\
\hline \multirow{4}{*}{$\begin{array}{l}\text { (a) analysis of existing } \\
\text { capacities (zones according } \\
\text { to the existing plan, active } \\
\text { and non-active) }\end{array}$} & number and size of zones (m2) & 5 \\
\hline & $\begin{array}{l}\text { ownership of land and buildings } \\
\text { (private, municipalities, other) }\end{array}$ & 3 \\
\hline & reserved land & 2 (difficult to define) \\
\hline & level of municipal services & 2 (difficult to define) \\
\hline \multirow{4}{*}{$\begin{array}{l}\text { (b) analysis of potential } \\
\text { capacities (new locations } \\
\text { provided for - empty } \\
\text { greenfield land) }\end{array}$} & Number and size of zones & 4 \\
\hline & $\begin{array}{l}\text { Ownership of land and buildings } \\
\text { (private, municipalities, other) }\end{array}$ & 4 \\
\hline & Reserved land & 4 \\
\hline & Level of municipal services & 4 \\
\hline \multirow{4}{*}{$\begin{array}{l}\text { (c) analysis of development } \\
\text { initiatives provided during } \\
\text { OPN production and in } \\
\text { interviews }\end{array}$} & formal initiatives (number and scope) & 4 \\
\hline & $\begin{array}{l}\text { non-formal initiatives (positions of } \\
\text { decision-makers) }\end{array}$ & 3 \\
\hline & $\begin{array}{l}\text { non-formal initiatives (positions of } \\
\text { local entrepreneurs) }\end{array}$ & 3 \\
\hline & $\begin{array}{l}\text { plausibility of initiatives (assessment } \\
\text { of actual needs) }\end{array}$ & 2 (difficult to define) \\
\hline $\begin{array}{l}\text { (d) other sources of acquiring } \\
\text { data on needs }\end{array}$ & $\begin{array}{l}\text { situation in the market (supply and } \\
\text { actual demand) }\end{array}$ & 2 (difficult to define) \\
\hline $\begin{array}{l}\text { (e) consideration of } \\
\text { guidelines of umbrella } \\
\text { documents }\end{array}$ & $\begin{array}{c}\text { sustainable development objectives as } \\
\text { determined by strategic regional and } \\
\text { national plans }\end{array}$ & 3 (difficult to define) \\
\hline $\begin{array}{l}\text { (f) consideration of } \\
\text { guidelines by those } \\
\text { responsible for spatial } \\
\text { development }\end{array}$ & $\begin{array}{c}\text { spatial restrictions, sector } \\
\text { conditionality, and protection and } \\
\text { management schemes }\end{array}$ & 5 \\
\hline \multicolumn{3}{|l|}{$\begin{array}{c}\text { Activity - producing the } \\
\text { draft of a zone development } \\
\text { strategy }\end{array}$} \\
\hline \multirow{6}{*}{$\begin{array}{l}\text { (g) definition of location- } \\
\text { specific criteria for planning } \\
\text { new zones and further } \\
\text { development of the operation } \\
\text { at existing locations }\end{array}$} & Actual needs (no reliable data) & 2 (difficult to define) \\
\hline & Spatial capacities & 4 \\
\hline & Transport accessibility & 5 \\
\hline & Environmental impacts & 3 \\
\hline & Economic background & 3 \\
\hline & Construction costs & 2 (difficult to define) \\
\hline
\end{tabular}

Based on the interim results we selected a structural set of starting points. We found that, according to their "strategic status", we can distinguish between:

(1) General starting points (and guidelines), which mostly arise from the hierarchy of development documents (state, region, municipality). In the process of plan production they represent an "orientation" only, without specifically defined and quantified consequences that the zones would trigger in the economic and/or spatial sense. 
(2) Specific starting points obtained during the production of the expert study for plan preparation. They provide the basis for planning the locations of zones, their dimensions, and the programmatic design.

According to their impact they were divided into two basic groups: (a) economic starting points (justifying the meaning of a zone as an instrument for encouraging economic development) and (b) spatial starting points (justifying the meaning of a zone as an instrument for regulating spatial activities) (Table 4).

Table 4. Economic and spatial starting points influencing the concept of business zone development in the analysed documents.

\section{A - ECONOMIC STARTING POINTS}

justifying the meaning of a zone as an instrument for encouraging economic development

A1 - global starting points, justifying the synergy between the zones and the national economy

(e.g., zones in the function of an instrument for drawing on financial incentives used by the state to encourage economic development through the shaping of a competitive business environment, attracting FDI, etc.)

A2 - specific local starting points (known needs of local entrepreneurs or creation of real spatial

reserves for potential external entrepreneurs) quantifiable effect of the new zone (number of jobs, taxes, income tax, etc.)

A3 - non-specific local starting points (establishing "reserve" zones, mostly real-estate interests, whose impact is difficult to quantify)

\section{B - SPATIAL STARTING POINTS}

justifying the meaning of a zone as an instrument for regulating spatial activities

B1 - global planning starting points, justifying the synergy between the zones and general spatial development

(impact is difficult to quantify e.g. zones in the function of an instrument for regulating the environmental

impacts, distribution of jobs, transport rationalisation, etc.)

A2 - specific planning starting points (known needs regarding the number, size, typology of zones. These needs

are: founded based on known actual or envisaged development initiatives, development potential of the

existing zones, and the real-estate market situation)

A2 - specific project starting points (known detailed demands for the planning of buildings within zones, known

locational characteristics and restrictions, envisaged environmental impacts, known guidelines of those

responsible for spatial planning)

Over the last 25 years, both general (desired global impacts of zones) and specific starting points (detailed parameters on the number, size, and typology of zones in a specific territory defined by a relevant document) were considered practically in all new plans; therefore it is incomprehensible that nowadays there is such a dichotomy between the large number of realised zones and, at the same time, their inefficiency both in the programmes 
for encouraging economic development as well as in the process of steering spatial development. This is the consequence of various conditions. Based on the analysis, the following conclusions were drawn:

(1) The problems of "efficiency of old zones" in the process of plan production and in their development promotion, particularly in the difficulty of defining their "actual development potential":

(a) spatial reserves within the existing zones are minimal and/or not available, (b) prevalence of complex ownership structure (result of non-systematic privatisation of social property), lack of data on the condition of infrastructure, interests regarding the shift of business and sale of real-estate, (c) unpredictable land prices of existing zones in the coastal zone and in the vicinity of urban centres, (d) non-digitised maps and obsolete regulations for urban and architectural design reflected in a diverse (or uncontrolled) image of the urban fabric (visually unattractive business environment).

(2) The problems of "efficiency of new zones" are mostly: (a) non-competitive land prices, (b) inefficient system of promotion and marketing, (c) inefficient system of joint management, (d) location; real-estate interests often affected the establishment of new zones (drawing on EU funds, single profit from the sale of developed land, etc.) rather than actual needs. Thus, locations were often selected that did not meet the criteria for zone construction - such zones will never thrive as efficient development zones.

\section{Discussion}

The planning and design of business zones in RS over the past 25 years was influenced by the following starting points: (a) strategic development starting points at national, regional, and local levels (to a smaller degree), (b) "implementing project" starting points (specific development needs at the local level - to a smaller degree), (c) real-estate motivations (to a larger degree), and (d) established spatial conditions as a legacy of former plans (the most). This study revealed that despite the ambitiously set development strategies, the zones in their current spatial, administrative, and market form are not an efficient enough instrument to steer spatial development. Based on this finding, we can fully confirm the hypothesis developed. In this framework, the results of the survey conducted among foreign investors (SPIRIT) become understandable, and can be interpreted as a suggestion for improving the existing situation. Based on these findings, we propose the following amendments:

(a) to elaborate a strategy for further development of zones at all levels of spatial documents, which would include priority locations, a uniform typology, and a timeline of their development (in the future, this is the basis for selectively guiding financial subsidies and other actions to boost competition), (b) form an efficient system for data updating (on free capacities, programmatic direction, public utilities, etc.), (c) in larger zones to set up a system of joint management, marketing, and promotion.

\section{Conclusions}

The planning and design of business zones, as a regulating instrument, is a complex social, professional, and administrative process. Despite the ambitiously set strategies for achieving global competitiveness, their impact is neutralised mostly at the implementing level. To achieve the desired efficiency in the field, a highly interdisciplinary approach and understanding of all parameters of the "current market economy" in the wider European space are needed. 


\section{References}

1. Agenda 21: Programme of Action of Sustainable Development (United Nations Conference on Environment \& Development, Rio de Janeiro, 1992)

2. ESDP European Spatial Development Perspective (Potsdam, 1999)

3. G. Balažič, Relikt socializma v prostoru - primer mestne občine Koper, diplomska naloga, Fakulteta za humanistične študije (Univerza na primorskem, Koper, 2006)

4. R. M. Agosin, R. Mayer, Foreign Investment in Developing Countries. Does it Crowd in Domestic Investment? Discussion Paper No. 146 (UNCTAD, Ženeva, 2000)

5. P. A. Maksimenko, M. Rojec, Foreign investment and privatization in Eastern Europe (Palgrave Publishers, Hampshire, 2001)

6. J. H. Dunning, Assessing the Costs and Benefits of Foreign Direct Investment: Some Theoretical Considerations, in: M. Patrick Artisien, M. Rojec (Eds.), Foreign Investment and Privatization in Eastern Europe (Houndmills, Basingstoke, Palgrave. 2001)

7. K. Dimitrovska-Andrews, Local land \& soil news, 6/II, (2003) 25-26.

8. Spatial Development Policy of the Republic of Slovenia (MOP-UPP, Ljubljana, 2002)

9. SGRS - Slovenija v novem desetletju: trajnost, konkurenčnost, članstvo v EU. Urad RS za makroekonomske analize in razvoj (Ljubljana, 2001)

10. Ordinance on Spatial Planning Strategy of Slovenia, Official Gazette of the RS (2004)

11. Regionalna zasnova prostorskega razvoja JV Slovenije (Acer, Novo mesto, 2006)

12. Regionalna zasnova prostorskega razvoja južne Primorske: Analiza stanja in razvojnih možnosti ter vizija prostorskega razvoja regije (Acer, Novo mesto, 2006)

13. Regionalni razvojni program za Južno Primorsko regijo 2007-2013 (RRC Koper, Koper, 2006)

14. Municipal Spatial Plan of the Municipality of Žalec, Official Gazette of the RS, No. 64/2013 (2013)

15. Municipal Spatial Plan of the Municipality of Piran (OPN) - strategic part, draft (LUZ, Ljubljana, 2010)

16. Municipal Spatial Plan of the Municipality of Izola (OPN) - strategic part, draft (Locus, Domžale, 2013

17. Municipal Spatial Plan of the City Municipality of Novo mesto, Official Gazette of the RS, No. 101/2009.

18. Municipal Spatial Plan of the City Municipality of Ljubljana, Official Gazette of the RS, No. 87/2010 (2010)

19. J. Kušar, G. Čok, U. Račečič Skrt, T. Berčič, Strokovne podlage za gospodarska in industrijska območja: strokovne podlage za pripravo SPRO in PRO občine Žalec (Univerza v Ljubljani, Fakulteta za arhitekturo, Uniarh, Ljubljana, 2006)

20. G. Čok, D. Kavaš, M. Košak, M. Koman, M. Čok, Delo in turizem na domu: strokovne podlage za pripravo OPN Občine Piran (U-M-A, Lokev, 2007)

21. M. Plazar Mlakar, A. Mlakar, L. Gosar, G. Čok, D. Kavaš, J. Hudoklin, M. Bidovec, I. Selak, T. Jerin, M. Kocjančič, J. Bagon, Analiza stanja in teženj v prostoru za SPRO inPRO Občine (Studio Mediterana, Izola, 2007)

22. R. Alihodzic, V. Murgul, N. Vatin, Applied Mechanics and Materials, 680, 494-498 (2014)

23. G. Radovic, V. Murgul, N. Vatin, Applied Mechanics and Materials, 641-642, 634638 (2014) 